chorych dzieci i ich rodzin, ale także wszystkim tym, którzy troszczą się o los i dobro człowieka znajdującego się w trudnych sytuacjach życiowych, którym bliskie są kwestie opieki i pomocy dla najbardziej jej potrzebujących.

Mirosław J. Szymański*

\title{
Malgorzata Fopka-Kowalczyk, Poczucie straty po śmierci pacjenta wśród pracowników opieki paliatywnej, Toruń: Wydawnictwo Naukowe Uniwersytetu Mikołaja Kopernika, 2016, s. 600.
}

DOI: http://dx.doi.org/10.12775/PCh.2017.020

Wśród publikacji Wydawnictwa Naukowego Uniwersytetu Mikołaja Kopernika w Toruniu w 2016 roku ukazała się książka Małgorzaty Fopki-Kowalczyk pod tytułem Poczucie straty po śmierci pacjenta wśród pracowników opieki paliatywnej. Autorka, związana naukowo z Wydziałem Nauk Pedagogicznych Uniwersytetu Mikołaja Kopernika w Toruniu, od 2001 roku pracuje także jako psycholog w Hospicjum „Światło” w Toruniu. Jej działania obejmowały tam wsparcie osób znajdujących się u kresu życia oraz ich bliskich, a także pracowników i wolontariuszy. Prezentowana książka mieści się w obu obszarach działalności Autorki - praktycznym i teoretycznym, ukazując interesujące badania w obrębie praktyki na tle dotychczasowej wiedzy teoretycznej na temat opieki paliatywno-hospicyjnej w Polsce. Książka jest fragmentem obszerniejszej dysertacji doktorskiej pod tytułem Wsparcie społeczne pracowników hospicjum a poczucie straty po śmierci pacjenta ${ }^{1}$, przedłożonej i obronionej w 2013 roku na Uniwersytecie Mikołaja Kopernika w Toruniu.

Rozdział pierwszy książki poświęcony został hospicjum w ujęciu teoretycznym. Autorka szeroko opisuje hospicjum, począwszy od wyjaśnienia terminu, przez historię powstania tego typu placówki, po charakterystykę interdyscyplinarnej opieki nad pacjentem u kresu życia. Treści zawarte w tej części są z zasady zgodne z ostatnimi znaczącymi publikacjami z tej dziedziny ${ }^{2}$. $\mathrm{Na}$

* Prof. dr hab. Mirosław J. Szymański jest kierownikiem Katedry Socjologii Edukacji w Instytucie Pedagogiki Akademii Pedagogiki Specjalnej w Warszawie. Adres: Instytut Pedagogiki APS, ul. Szczęśliwicka 40, 02-353 Warszawa; e-mail: miroslaw.szymanski@wp.pl.

${ }^{1}$ Praca doktorska znajduje się w archiwum BUMK w Toruniu.

2 Por. Piotr Krakowiak, „Cześć i historia”, w: Solidarni. Dzieje opieki paliatywno-hospicyjnej w Polsce, red. Anna Janowicz, Piotr Krakowiak, Alicja Stolarczyk (Gdańsk: Fundacja Hospicyjna 2015), 32-63. 
szczególną uwagę zasługuje zwrócenie przez Autorkę uwagi na pozamedyczne aspekty opieki, uwzględniające opiekę psychologiczną, pedagogiczną, wsparcie pracownika socjalnego, a także szeroko pojętą opiekę duchową nad pacjentem. Przydałoby się w tym miejscu więcej odniesień do literatury przedmiotu w tej właśnie kwestii, szczególnie do publikacji odnoszącej się do charakterystyki opieki holistycznej ${ }^{3}$. Szerokie omówienie charakterystyki placówki, na tle której analizowane są przeprowadzone przez autorkę działania badawcze, pozwala czytelnikowi pełniej rozumieć treści ukazane w kolejnych rozdziałach, a samodzielnie rozpatrywane stanowi źródło usystematyzowanej wiedzy na temat genezy opieki paliatywno-hospicyjnej w Polsce. Brakiem wynikającym być może z terminu złożenia pracy do publikacji jest niewykorzystanie przywołanej już pierwszej tego typu monografii dziejów ruchu hospicyjnego w Polsce, opublikowanej w 2015 roku$^{4}$.

Rozdział drugi zatytułowany: „Pracownicy hospicjum po śmierci pacjenta. Poczucie straty", skoncentrowany jest na literaturze przedmiotu. Autorka przywołuje specyfikę relacji personelu hospicyjnego z chorym, a także zagadnienia żałoby i zjawiska straty u pracowników medycznych i pozamedycznych w świetle dotychczasowych badań. Śmierć i żałoba ukazane są nie tylko w aspekcie biologiczno-emocjonalnym, ale zasygnalizowane są różne paradygmaty i koncepcje, w jakich zagadnienie to może być przedstawiane i rozumiane. Wskazany został paradygmat kognitywistyczny (George Kelly, Mardi Hotwitz, Charles Kalish) koncentrujący się na zmianach poglądów, myślenia i postrzegania rzeczywistości za sprawą zaistniałego zdarzenia, jakim jest śmierć (s. 78). Inną perspektywą, przywołaną przez Autorkę, jest perspektywa fenomenologiczno-egzystencjalna żałoby. Opiera się ona na trudnym doświadczeniu nieistnienia człowieka w wyniku jego śmierci i trudności budowania relacji społecznych w nowej rzeczywistości naznaczonej żałobą. Koncepcje te są punktem wyjścia do rozumienia przebiegu żałoby i poczucia straty przez osoby jej doświadczające, w tym przez pracowników opieki paliatywnej. Novum tego ujęcia wynika z faktu, że badani są pracownicy - osoby o formalnej relacji z pacjentem. Badania Małgorzaty Fopki-Kowalczyk są interesującym dopełnieniem badań istniejących na gruncie polskim i zagranicznym, o czym także wspomniano w niniejszej publikacji. Autorka powołuje się na Elżbietę Gregorasz (s. 91), Mirosława

3 Por. Józef Binnebesel, Piotr Krakowiak, Anna Janowicz, Agnieszka Paczkowska, Pozamedyczne aspekty opieki paliatywno-hospicyjnej (Gdańsk: Fundacja Hospicyjna, 2010).

${ }^{4}$ Solidarni. Dzieje opieki paliatywno-hospicyjnej w Polsce, red. Anna Janowicz, Piotr Krakowiak, Alicja Stolarczyk (Gdańsk: Fundacja Hospicyjna, 2015). 
Góreckiego (s. 93), Jana Bieleckiego (s. 93) na gruncie polskim i na podstawie literatury zagranicznej wyróżnia, ale nie omawia: Kim Andresen, Anette Van-Hein Wallace i innych (s. 94). Wniosek wynikający z teoretycznego oglądu tematu wskazuje, że profesjonalni opiekunowie narażeni są na sytuacje trudne, związane $\mathrm{z}$ umieraniem i śmiercią pacjenta, a także poczuciem straty w związku z zaistniałą sytuacją.

Rozdział trzeci stanowi metodologiczne wprowadzenie do planowanych badań opartych na teorii ugruntowanej. Przedstawione zostały eksploracyjne, sondażowe badania jakościowe, dotyczące reakcji personelu zespołów opieki paliatywnej po śmierci pacjenta. Autorka własne badania projektuje w paradygmacie interpretatywnym i strategii jakościowej: starając się odnaleźć odpowiedzi na pytania: czy wśród pracowników opieki paliatywnej występują reakcje na poczucie straty po śmierci pacjenta oraz jakie reakcje występują wśród pracowników opieki paliatywnej po śmierci pacjenta, z którym nawiązana została bliższa znajomość? Badanymi było 20 osób z 6 ośrodków opieki paliatywnej w województwie kujawsko-pomorskim, a analiza uzyskanego materiału oparta była na metodologii teorii ugruntowanej Anselma Straussa i Barneya Glesera ${ }^{5}$.

Rozdział czwarty jest prezentacją wyników wywiadów pogłębionych, skoncentrowanych na problemie oraz prezentacją implikacji dla pedagogiki i psychologii. Uzyskane wyniki zestawione zostały w trzech kategoriach reakcji: emocjonalnej, poznawczej i somatyczno-behawioralnej oraz opisane z zastosowaniem cytowań wypowiedzi osób badanych, co dobrze ukazuje poszczególne reakcje opiekunów na śmierć chorego i poczucie straty w jej wyniku. Wyniki wskazują jednoznacznie, że u badanych występują reakcje w każdym z obszarów wskazanych przez autorkę: reakcje emocjonalne, takie jak żal, poczucie bezradności, poczucie niesprawiedliwości; reakcje poznawcze - wspominanie chorego, dylematy moralne, stosunek do śmierci i reakcje somatyczno-behawioralne - płacz, ukrywanie własnych emocji, bezsenność i inne. Wnioski z badań pokrywają się ze znanymi z literatury przedmiotu danymi, a cenną wartością recenzowanej publikacji jest możliwość implikacji wyników do praktyki opiekuńczej dla badanych ośrodków w województwie kujawsko-pomorskim.

Autorka w swojej książce powołuje się głównie na literaturę polską i jedynie te badania przywołuje w kontekście ich wyników oraz grupy badawczej. Kwestia braku badań zagranicznych nieco spłyca kontekst i z pewno-

5 Anselm Strauss, Barney Gleser, The Discovery of Grounded Theory: Strategies for Qualitative Research (New Brunswick: Routledge, 1967). 
ścią w kolejnym wydaniu tego dzieła warto byłoby uzupełnić je o dokonania w tym zakresie na gruncie międzynarodowym, szczególnie w literaturze w języku angielskim.

Niewątpliwą zaletą tej publikacji jest jej walor edukacyjny i praktyczny, co lokuje recenzowane dzieło w przestrzeni pedagogiki opiekuńczej i pracy socjalnej. Wiedza na temat form przeżywania straty i jej obszarów może być bazą do stworzenia modelu wsparcia dla opiekunów profesjonalnych doświadczających straty. Autorka podkreśla, że jedna z metod radzenia sobie z sytuacją trudną - superwizja - w warunkach polskich zarezerwowana jest jedynie dla psychologów i stanowi dość ekskluzywny sposób dbania o własne umiejętności interpersonalne i kompetencje merytoryczne w pracy. Należy w pełni zgodzić się z nią i stwierdzeniem, iż brakuje innych form, mogących pomóc $\mathrm{w}$ sytuacji trudnej osobom niebędącym psychologami w zespołach opiekuńczych. Książka zakończona jest wnioskiem praktycznym, by sugerować dyrektorom placówek opieki paliatywnej tworzenie grup wsparcia i grup samopomocowych dla wszystkich osób, które pracują z pacjentem, a nie tylko dla psychologów, którzy zazwyczaj dysponują taką formą pomocy. Ten końcowy postulat autorki w pełni wpisuje się w zapisane w dokumentach polityki społecznej polecenia superwizji dla pracy socjalnej, coraz częściej realizowane w praktyce opiekuńczej ${ }^{6}$.

Podsumowując, należy stwierdzić, iż niniejsza publikacja napisana jest w sposób ciekawy, usystematyzowany i może stanowić cenne źródło wiedzy dla osób pracujących w zespołach opiekuńczych. Z pewnością książkę tę można zaproponować także studentom kierunków ,pomocowych” i wszystkim innym osobom, zapoznającym się z tematem opieki paliatywno-hospicyjnej z myślą o wolontariacie czy rozważającym umieszczenie tam swoich bliskich. Wyniki badań własnych autorki stanowią źródło rozumienia doświadczeń opiekunów i wskazują na wieloaspektowość przeżywania straty i żałoby, dopełniając i porządkując w przystępny sposób wiedzę dostępną w tym zakresie. Publikacja jest warta polecenia profesjonalistom, studentom, wolontariuszom i rodzinom osób u kresu życia, a także tym wszystkim, którzy wobec straty i żałoby pragną przyjść innym z pomocą.

\section{Karolina Kramkowska*}

${ }^{6}$ Superwizja pracy socjalnej, red. Mirosław Grewiński (Warszawa: Wydawnictwo Wyższej Szkoły Pedagogicznej im. Janusza Korczaka w Warszawie, 2013).

* Mgr Karolina Kramkowska jest doktorantką na Wydziale Pedagogiki i Psychologii Uniwersytetu Kazimierza Wielkiego w Bydgoszczy. Adres: Wydział Pedagogiki i Psycho- 


\section{Bibliografia}

Binnebesel, Józef, Piotr Krakowiak, Anna Janowicz, Agnieszka Paczkowska. Pozamedyczne aspekty opieki paliatywno-hospicyjnej. Gdańsk: Fundacja Hospicyjna, 2010.

Superwizja pracy socjalnej, red. Mirosław Grewiński. Warszawa: Wydawnictwo Wyższej Szkoły Pedagogicznej im. Janusza Korczaka w Warszawie, 2013.

Krakowiak, Piotr. „Cześć i historia”. W: Solidarni. Dzieje opieki paliatywno-hospicyjnej w Polsce, red. Anna Janowicz, Piotr Krakowiak, Alicja Stolarczyk, 32-63. Gdańsk: Fundacja Hospicyjna, 2015.

Strauss, Anselm, Barney Gleser. The Discovery of Grounded Theory: Strategies for Qualitative Research. New Brunswick: Routledge, 1967.

\section{Mirosław J. Szymański, Błażej Przybylski (red.), W kręgu wspótczesnych problemów edukacyjnych, Warszawa: Wydawnictwo Akademii Pedagogiki Specjalnej im. Marii Grzegorzewskiej, 2015, s. 254.}

DOl: http://dx.doi.org/10.12775/PCh.2017.021

W 2015 roku na rynku wydawniczym ukazała się książka pod redakcją Mirosława J. Szymańskiego i Błażeja Przybylskiego: $W$ kręgu współczesnych problemów edukacyjnych. Stanowi ona zbiór artykułów, których autorami są pracownicy Akademii Pedagogiki Specjalnej im. Marii Grzegorzewskiej w Warszawie oraz osoby współpracujące z tą uczelnią. Poruszają oni wiele ważnych i aktualnych problemów edukacyjnych ${ }^{1}$, nierzadko ukazując je w kontekście dokonujących się przemian społecznych, politycznych, kul-

logii Uniwersytetu Kazimierza Wielkiego w Bydgoszczy, ul. Jana Karola Chodkiewicza 30, 85-064 Bydgoszcz; e-mail: karolinakramkowska@gmail.com.

${ }^{1}$ Wybranym problemom współczesnej edukacji poświęcono w ostatnich latach m.in. następujące publikacje: Problemy edukacji jutra $w$ dobie globalizacji, red. Kazimierz Denek, Aleksandra Kamińska, Piotr Oleśniewicz (Sosnowiec: Oficyna Wydawnicza „Humanitas”, 2012); Problemy edukacji w społeczeństwie wiedzy, red. Stanisław Juszczyk (Katowice: Wydawnictwo Uniwersytetu Śląskiego, 2012); Oblicza edukacji w zmieniającym się spoleczeństwie, red. Agata Popławska (Białystok: Wydawnictwo Niepaństwowej Wyższej Szkoły Pedagogicznej, 2012); Mirosław J. Szymański, Edukacyjne problemy współczesności (Kraków-Warszawa: Oficyna Wydawnicza „Impuls”, 2014); Współczesne problemy edukacji w Polsce, 